\title{
POLLUTION IMPACT OF CEMENT PRODUCTION ON AIR, SOIL AND WATER IN A PRODUCTION LOCATION IN NIGERIA
}

\author{
K. Ogedengbe ${ }^{1}$ and A. O. Oke ${ }^{2}$ \\ ${ }^{I}$ Department of Agricultural \& Environmental Engineering, Faculty of Technology, University of \\ Ibadan, Nigeria. \\ kolaogedengbe@yahoo.com \\ ${ }^{2}$ Land and Water Resources Management Programme, Institute of Agricultural Research and \\ Training, Obafemi Awolowo University, Moor Plantation, Ibadan, Nigeria \\ bayooke1410@gmail.com
}

\begin{abstract}
Environmental pollution caused by the activities of Ewekoro Cement production facility of the West African Portland Cement (WAPC, Plc), Ogun State, Nigeria was studied at some terrestrial and aquatic receptor locations within the catchments area of the production plant which has been in operation for over 40years. Air, water and soil samples of the adjoining villages (Ajobiewe, Olapeleke, Alaguntan and Wasinmi) were analyzed. High particulate matter depositions were recorded for all the sampling locations. Dusts emitted from the cement factory were rich in heavy metals. Heavy metals concentration at Ajobiewe, Olapeleke and Alaguntan were significantly $(p<0.05)$ higher compared with those obtained at Wasimi - the farthest location from the pollution source, which served as control for particulate and soil sampling. The distribution of heavy metals in the soil sampled followed in decreasing order of $\mathrm{Mn}>\mathrm{Ni}>\mathrm{Fe}>\mathrm{Cr}>\mathrm{Zn}>\mathrm{Cu}>\mathrm{Co}>\mathrm{Pb}>\mathrm{Cd}$. Heavy metals concentrations were significantly different $(p<0.05)$ at the closest locations around the plant compared to Wasinmi (the control). Basic cations and anions in the water samples from the 3 rivers draining the area were within internationally recommended values for irrigation except the electrical conductivity $(E C)$ and nitrate $\left(\mathrm{NO}_{3}{ }^{-}\right)$in Alaguntan River which were found to be above the maximum permissible limits by $5.41 \%$ and $64.30 \%$ respectively. Comparatively, heavy metals concentration were significantly higher $(p<0.05)$ in samples from Alaguntan River than in corresponding sample from Elebute and Itori Rivers. Heavy metals concentration in these rivers were high compared to similar rivers at other places with no cement production. These elevated heavy metal levels may be a limitation to using the rivers for irrigation.
\end{abstract}

Keywords: Cement production, Pollution, Heavy metals, Particulate deposition, irrigation.

\section{INTRODUCTION}

Environmental pollution is a direct result of human, social and industrial activities which often initiates undesirable changes in the ecosystem, creating some imbalances in physical, chemical and biological dynamics of the environment. Generally, industrial activities rank higher among contributors to environmental degradation. Metal mining, smelting and meat processing, oil and gas exploration, petro- 


\section{7}

\section{Ogedengbe and Oke}

chemical manufacturing and such other industrial activities have severe impact on the fragile ecosystem. These negative impacts on the environment are from direct results of production activities or by the release of waste and by products which often are toxic in their untreated states.

Cement manufacturing is known to emit about $500-1700 \mathrm{~kg}$ of particulate matter daily (ETPI, 1991). A study in the United States of America reported a dirt level ranging from $26-114 \mathrm{mg}$ / $\mathrm{m}^{3}$. (U.S. Census Bureau, 2000). Studies have shown that soil, ambient air and surface water within the vicinity of a cement factory are seriously degraded (Farmer, 1993). Andrey (1987) reported an incidence of elevated concentration of $\mathrm{Fe}, \mathrm{Mg}, \mathrm{Pb}, \mathrm{Zn}, \mathrm{Cu}, \mathrm{Be}$, Tetraoxosulphate VI and $\mathrm{HCl}$ among cement plant wastes. Similarly, Sivakumar and Britto, (1995) and Jalken et al. (2000) reported an elevated deposit of alkali earth metal and heavy metals such as As, $\mathrm{Pb}, \mathrm{Ni}, \mathrm{Co}, \mathrm{Zn}, \mathrm{Cu}$ and Phosphorous from cement dust and other particles with attendant environmental risks.

There is a statistical significant relationships between symptoms of respiratory effects in humans to their proximity to cement kilns with $\mathrm{CO}_{2}, \mathrm{Cl}, \mathrm{F}, \mathrm{SO}_{2}$ and other sulphur oxides sources. (Legator et al. 1998). Volatile organic compounds and micro pollutants are usually released from cement factories (Vans Oss and Padovani, 2003). Ponsby et al. (2000), W.H.O (1999) and Wang et al. (1997) have all shown the negative impact of cement manufacturing activities on humans and the environment. Similarly, studies on the effect of cement dust on biosynthetic processes in plant also revealed reduction in chlorophyll and carotenoid content, impairing carbon IV oxide exchange and plant photosynthesis rate. (Lepedus et al., 2003; Cesar and Lepedus, 2001).

Also, cement production have been known to contribute to pollution of streams and rivers from the degraded runoff discharges from atmospheric deposition of contaminated particu- late matter, cooling water, leachates from stock piles raw material and effluents from quality control laboratories. These sources are among those identified by El Fadel et al. (2005); World Bank (1998) and Perfitini et al. (1989). Pollutants in water can remain in solution or deposited to form part of drainage sediments. Water quality is dependent on the total dissolved substances and these substances when dissolved in water react to change its chemical composition. Gaiero et al. (1997) stressed that heavy metals in river sediments are considered more sensitive than dissolved contamination as an indication of pollution.

This study evaluates the impact of cement production in a local community of Ewekoro, Ogun State in South western Nigeria with a view to quantify the status of air, soil and water within the neighborhood.

\section{MATERIALS AND METHODS}

The Ewekoro Cement plant, one of the leading cement manufacturing factories in Nigeria was chosen for this study. Cement production activities have been on for over four decades in this location. The factory utilizes wet and semi -wet production technology with the annual cement production varying between 254,000 and 479,000 metric tons (WAPC,2000). It is located $5 \mathrm{~km}$ from Ewekoro town $\left(6^{0} 55^{\prime} \mathrm{N}\right.$, $\left.3^{0} 12^{\prime} \mathrm{E}\right)$ in the Ogun State of South western Nigeria. A number of farm settlements preexisted the company and the cement production factory. These include Wasinmi and Itori to the north, Elebute and Alaguntan to the east and Olapeleke to the west of the factory within $10 \mathrm{~km}$ radius. (Figure 1). The catchment of the cement factory is drained perennially by Alaguntan, Elebute and Itori rivers. The farm settlements were named after these rivers because of their importance to agricultural activities in the area. Although, the rivers are ungauged and the capacity undetermined, local farmers have relied on the discharges of these rivers to support their irrigation farming activities during the dry season. They are major tributaries to 
Ewekoro river which drains into the Ogun River, the major river of the Ogun-Osun River Basin.

Ewekoro town is located within the tropical rainforest vegetation belt of Nigeria with annual mean temperature of $30^{\circ} \mathrm{C} \pm 10^{\circ} \mathrm{C}$, relative humidity $65 \pm 10 \%$ and average rainfall of $1500 \mathrm{~mm} \pm 120 \mathrm{~mm}$ (Oguntoyinbo et al., 1983). The average wind speed at a height of $10 \mathrm{~m}$ above ground level was $1.0 \mathrm{~m} / \mathrm{s}$ between January - March and $0.72 \mathrm{~m} / \mathrm{s}$ between MayNovember (IITA, 2000). The deposition of cement dust and other particulate matter over the catchment was therefore very noticeable and of serious concern to the local community.

\section{Sampling Sites}

Various sites were considered suitable for sample collections based on their location upstream and downstream of the cement factory. The Alaguntan, Elebute and Itori Streams (Fig.1) were selected for surface water pollution studies. For the soils and air pollution, Ajobiewe village $(0.1 \mathrm{~km} \quad$ South), Olapeleke $(1.0 \mathrm{~km}$ West), Alaguntan (1.5km East) and Wasinmi $(9.5 \mathrm{~km}$ North, and the farthest from the factory) were selected as sampling sites.

\section{Soil Sampling}

Soil samples from four farming villages (Ajobiewe, Olapeleke, Alaguntan and Wasinmi) were collected. Twenty random samples taken at a depth of $0-20 \mathrm{~cm}$ from different location were taken bulked together and thoroughly mixed in a composite for each of the location. The composite samples were put in clean airtight plastic container for laboratory analysis.

\section{Water Sampling}

The Alaguntan, Elebute and Itori Streams were sampled weekly for 3 weeks during the usual period of high irrigation activities. Ten (10) 1 litre samples of water were taken using clean dry 1-litre wide mouthed transparent glass bottle at interval of $20 \mathrm{~m}$ apart along each of the river courses at a depth of $15 \mathrm{~cm}$ from the surface. The collected samples were mixed into a composite for each stream and appropriately labeled for laboratory analysis within the 72hours of sampling. The sample bottles were previously soaked in soap solution treated with $5 \% \mathrm{HNO}_{3}$ for 24Hours and rinsed severally with distilled water prior to use (DWAF, 1992; DWAF, 1999).

\section{Air Sampling}

Samples of air in Ajobiewe, Olapeleke, Alaguntan and Wasinmi villages were sampled for particulate matter deposition. Ten clean Petri dishes, $12-20 \mathrm{~cm}$ diameter previously weighed and labeled were carefully placed on rooftop of residential buildings for three weeks at each of the sampling locations. The Petri dishes were previously soaked in soap solutions treated with $5 \% \mathrm{HNO}_{3}$ for 24 hours rinsed severally with distilled water and dried in oven prior to use. Similarly, treated clean brush and scoop were used to remove the deposited dust from the Petri dishes into a clean air tight plastic container for each of the locations and were appropriately labeled for analysis. The Wasinmi village is the farthest from the factory location and therefore considered as the control in this study.

The samples were subjected to Flame Photometry and Atomic Absorption Spectophotometry (AAS) analysis (APHA, 1992). The analysis were done within 72 hours after sample collection, thus there was no special need for pretreatment for storage (Chapman and Kimstach, 1996). All the analyses were done at the Analytical Laboratory of the International Institute of Tropical Agriculture (IITA) Ibadan.

\section{RESULTS AND DISCUSSION}

\section{Particulate Matter Deposition}

Particulate matter deposition constituted major atmospheric pollution issue in the cement plant and the auxiliary environment. This can be attributed to dust released during quarry activities, dust re-mobilization from vehicular traffic 


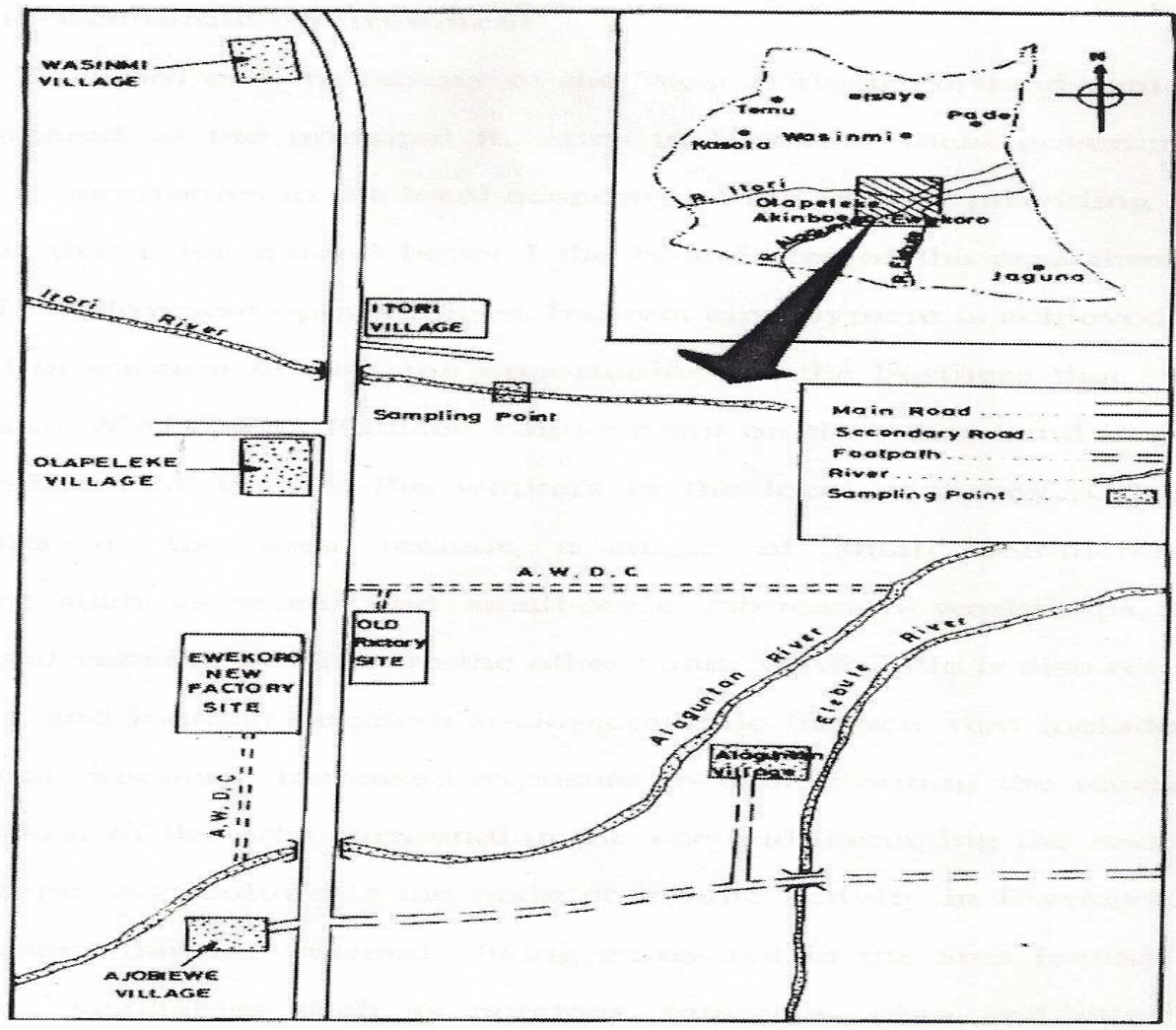

Fig. 1: Map of the study sites

Table 1: Particulate Matter Deposition Rate

\begin{tabular}{ll}
\hline Location & $\begin{array}{l}\text { Rate of Deposition } \\
\left(\boldsymbol{\mu g} / \mathbf{c m}^{2} . \text { day }\right)\end{array}$ \\
\hline Ajobiewe & 699 \\
Olapeleke & 134 \\
Alaguntan & 96 \\
Wasinmi & 58 \\
\hline
\end{tabular}

on paved and un-swept paved road, wind action on open piles of clinker and kiln stack losses. High values of particulate matter deposition were recorded with the highest being $699 \mu \mathrm{g} /$ $\mathrm{cm}^{2}$ day at Ajobiewe and the least being $58 \mu \mathrm{g} /$ $\mathrm{cm}^{2}$ day at Wasinmi (Table 1). These values indicate a differential deposition rate which may be due to location and distance from the cement factory, wind action, and gravity. The distances to the pollution source in order of closeness were Ajobiewe, Olapeleke, Alaguntan and Wasinmi. It was discovered that the concentration of the investigated heavy metals in the particulate deposits decreased with increasing distance from the pollution source (Table 2). In all the cases ( $\mathrm{Mn}, \mathrm{Fe}, \mathrm{Zn}, \mathrm{Cu}, \mathrm{Pb}$, $\mathrm{Ni}, \mathrm{Cr}, \mathrm{Co}, \mathrm{Cd})$, the impact of the produced dust on the environment decreased with increased distance from the pollution source. Wasinmi which was the control recorded the lowest concentration of heavy metals in particulate deposit while Ajobiewe the closest recorded the highest in all cases. Generally, concentration of heavy metals at Ajobiewe (the closest location to the pollution source was $\mathrm{Fe}>\mathrm{Zn}>\mathrm{Mn}>\mathrm{Cr}>\mathrm{Co}>\mathrm{Cu}>\mathrm{Pb}>\mathrm{Ni}>\mathrm{Cd}$ while at Wasinmi (the farthest-control), 
Table 2: Concentration of heavy metals in the sampled particulate deposited

\begin{tabular}{lllll}
\hline Elements $(\boldsymbol{\mu g} / \mathbf{g})$ & \multicolumn{2}{c}{ Locations } \\
& Ajobiewe & Olapeleke & Alaguntan & Wasinmi \\
\hline $\mathrm{Mn}$ & 70.2 & 53.11 & 45.92 & 15.91 \\
$\mathrm{Fe}$ & 1147.19 & 756.89 & 726.31 & 715.5 \\
$\mathrm{Zn}$ & 345.08 & 297.64 & 270.9 & 198.01 \\
$\mathrm{Cu}$ & 38.17 & 29.66 & 21.58 & 12.55 \\
$\mathrm{~Pb}$ & 36.9 & 18.91 & 10.82 & 9.15 \\
$\mathrm{Ni}$ & 33.05 & 25.1 & 18.22 & 15.75 \\
$\mathrm{Cr}$ & 55.12 & 26.04 & 17.54 & 11.11 \\
$\mathrm{Co}$ & 38.5 & 29.12 & 14.05 & 7.13 \\
$\mathrm{Cd}$ & 28.45 & 21.75 & 11.07 & 2.08 \\
\hline
\end{tabular}

$\mathrm{Fe}>\mathrm{Zn}>\mathrm{Mn}>\mathrm{Ni}>\mathrm{Cu}>\mathrm{Cr}>\mathrm{Pb}>\mathrm{Co}>\mathrm{Cd}$. At all the locations $\mathrm{Cd}$ concentration was the least while Fe was the highest recorded concentration. By simple proportion from (Tables 1 and 2), the rate of deposition of $\mathrm{Pb}$ was $0.0058 \mathrm{mg} / \mathrm{m}^{2}$ at Ajobiewe while at Wasinmi it was $0.0530 \mu \mathrm{g} /$ $\mathrm{m}^{2}$ or $0.000053 \mu \mathrm{g} / \mathrm{m}^{2}$. This is equivalent to deposition of $0.0530 \mathrm{~g}$ of $\mathrm{Pb}$ in every square kilometer per day. $\mathrm{Pb}$ and $\mathrm{Cd}$ have been found to be carcinogenic.

Similar trends have been reported in particulate matter deposited in areas surrounding the Jordan cement factory in the city of Fuhais, Jordan (Ziadat et al. 2006). In addition to the contribution from raw materials, the elevated concentration of $\mathrm{Fe}$ and $\mathrm{Mn}$ in the particulate deposited may be attributed to metal from wear machine parts. Zn elevated concentration may be linked with remobilization of dust by wind from disintegrated galvanized rooftops in the area while the exhaust emission from traffic and power generation from fossil fuel may have influenced the concentration of $\mathrm{Pb}$ as can be seen in Ajobiewe and Wasinmi which were very close to the major Lagos-Sango-Abeokuta road. The Duncan Multiple Range Test (DMRT) showed that the obtained concentration of heavy metals in Ajobiewe, Olapeleke and Alaguntan were significantly $(p<0.05)$ higher when compared with the values obtained at Wasinmi (the control) location. The value of $\mathrm{Fe}$ at Alaguntan was not significantly different $(\mathrm{p}<0.05)$.
However, the heavy metals concentration in soil studied are of the order of $\mu \mathrm{g} / \mathrm{g}$. The reason for this is because the particulate deposition is heavily laden with polluted metals which are easily and quickly moved by runoff into the receiving rivers from the soil surface. Nevertheless, it is clear from this study that the closer to the pollution source the greater the risk of elevated concentration of pollution (Gilbert, 2006; Meybeck et al. 1996), thus the less environmentally fit such location may be especially for agricultural purposes.

\section{Soil Quality Parameters}

The particle size distribution of the soil sample collected from the study area is shown in Table 3 . The soil quality parameters are reported in Table 4. The soil $\mathrm{pH}$ values were found to be between 10.96 at Ajobiewe and 7.39 at Wasinmi. This is indicative of alkaline soil. The other two locations have 8.03 and 7.46 in the order of their closeness to the pollution source. The general observation is that the $\mathrm{pH}$ of the study locations is Alkaline. The levels of Nitrogen $(\mathrm{N})$ and Organic Matter (OM) in the soil show same trends. Ajobiewe soil has the highest concentration of $\mathrm{N}(0.87 \mathrm{~g} / \mathrm{kg})$ while Wasinmi soil recorded the least concentration $(0.21 \mathrm{~g} / \mathrm{kg})$. This may be because of intense farming activities in Wasinmi and Olapeleke villages. Percentage OM was also highest in Ajobiewe samples and least in Wasinmi because of limited agricultural activities in the 


\section{Ogedengbe and Oke}

former as compared with the latter.

The concentrations of Phosphorous (P) in the soils were generally high. The degree of variation of the $\mathrm{P}$ concentration at different locations is shown in fig. 3. The high values of $\mathrm{P}$ concentration in all the soil may be due to phosphorous accumulation in the soil over a period of time. The soil pH (alkaline) causes phosphorous compound to have a form that the plant is unable to absorb (Ocak et al., 2004). Although P was about 200 times the concentration of $\mathrm{Ca}$ in all the locations, the predominance of lime in the area as raw material may have accounted for the high differences in $\mathrm{Ca}$ observed in all the locations. This may be a reflection of abundance of lime as raw material for cement production in the area. Increase in the amount of lime is related to the increase in $\mathrm{pH}$ of the polluted soil (Fabbri et al., 2004; Bayham et al., 2002). However, the electrical
(EC) and Sodium Adsorption Ratio (SAR) of the soil solution do not differ in trend and are indicative of a fertile soil.

An inverse relationship was observed between the concentration of heavy metals and the distance of the sampling locations from the polluted source. Similar to what obtained in the particulate deposition, Ajobiewe which is the closest recorded the highest concentration for all the heavy metals while Wasinmi which was the farthest had the least recorded concentration. The observed heavy metals concentration followed the same pattern $\mathrm{Mn}>\mathrm{Ni}>\mathrm{Fe}>\mathrm{Cr}>\mathrm{Zn}>\mathrm{Cu}>\mathrm{Co}>\mathrm{Pb}>\mathrm{Cd}$. The concentration of heavy metals in soil samples from Ajobiewe, Olapeleke and Algauntan show significant difference when compared with the heavy metals concentration from Wasinmi at $\mathrm{p}<0.05$ using the Duncan Multiple Range Test. Generally, the level of organic matter (OM)

Table 3: Particle size distribution of soil samples from studied locations

\begin{tabular}{lcccc}
\hline Sample Location & Sand \% & Silt \% & Clay \% & Textural Class \\
\hline Ajobiewe & 92.6 & 5.4 & 2 & Sand \\
Olapeleke & 82.6 & 9.4 & 8 & Loamy Sand \\
Alaguntan & 70.6 & 15.4 & 14 & Sandy Loam \\
Wasinmi & 93.6 & 4.4 & 2 & Sand \\
\hline
\end{tabular}

Table 4: Soil Quality Parameters of the Soil Samples

\begin{tabular}{llllll}
\hline Parameter & Unit & Ajobiewe & Olapeleke & Alaguntan & Wasinmi \\
\hline $\mathrm{pH}$ & & 10.96 & 8.03 & 7.46 & 7.39 \\
$\mathrm{~N}$ & $\mathrm{~g} / \mathrm{kg}$ & 0.87 & 0.25 & 0.56 & 0.21 \\
$\mathrm{OM}$ & $\%$ & 8.42 & 2.45 & 5.41 & 2.28 \\
$\mathrm{P}$ & $\mathrm{g} / \mathrm{kg}$ & 201.96 & 228.02 & 66.56 & 111.08 \\
$\mathrm{Ca}$ & $\mathrm{g} / \mathrm{kg}$ & 1.97 & 1.92 & 1.77 & 1.09 \\
$\mathrm{Mg}$ & $\mathrm{g} / \mathrm{kg}$ & 0.93 & 0.91 & 1.05 & 0.51 \\
$\mathrm{~K}$ & $\mathrm{~g} / \mathrm{kg}$ & 0.4 & 0.38 & 0.37 & 0.22 \\
$\mathrm{Na}$ & $\mathrm{g} / \mathrm{kg}$ & 0.21 & 0.2 & 0.19 & 0.12 \\
$\mathrm{EC}$ & $\mathrm{g} / \mathrm{kg}$ & 0.57 & 0.41 & 0.32 & 0.12 \\
$\mathrm{SAR}$ & $\mathrm{g} / \mathrm{kg}$ & 0.18 & 0.17 & 0.16 & 0.13 \\
\hline
\end{tabular}


content for an agricultural land is classified as low $(<1.5 \%)$ medium $(1.5 \%-2.5 \%)$ and high $(>2.5 \%)$. Therefore, Table 4 shows that all the soils were adequate in terms of fertility status. Also, the heavy metals in the soils were however found to be very high. High accumulation pollution. TDS values in Alaguntan, Elebute and Itori rivers are $473.60 \mathrm{mg} / 1,268 \mathrm{mg} / 1$ and $339.20 \mathrm{mg} / \mathrm{l}$ respectively.

Nitrate $\left(\mathrm{NO}_{3}{ }^{-} \mathrm{N}\right)$ and phosphate $\left(\mathrm{PO}_{4}{ }^{-} \mathrm{P}\right)$ levels obtained in Alaguntan River were $83.93 \mathrm{mg} / 1$

Table 5: Heavy metals in the soil of the study locations

\begin{tabular}{lllll}
\hline Element $(\mathbf{m g} / \mathbf{l})$ & & & & \\
& Ajobiewe & Olapeleke & Alaguntan & Wasinm \\
\hline $\mathrm{Mn}$ & 501.53 & 490.52 & 446.51 & 294.31 \\
$\mathrm{Fe}$ & 35.53 & 33.54 & 32.56 & 20.13 \\
$\mathrm{Zn}$ & 26.52 & 24.56 & 22.01 & 14.74 \\
$\mathrm{Cu}$ & 11.04 & 9.5 & 8.53 & 5.7 \\
$\mathrm{~Pb}$ & 3.71 & 3.35 & 3.05 & 2.01 \\
$\mathrm{Ni}$ & 43.56 & 41.52 & 37.54 & 24.91 \\
$\mathrm{Cr}$ & 34.58 & 32.5 & 29.01 & 19.5 \\
$\mathrm{Co}$ & 6.55 & 6.52 & 5.54 & 3.92 \\
$\mathrm{Cd}$ & 2.01 & 1.57 & 1.03 & 0.94 \\
\hline
\end{tabular}

of heavy metals in the soil can cause undesirable accumulation in the plant tissues and this may be harmful to the plants and the consumer.

\section{Water Quality Parameters}

Table 6 shows the Physico-chemical water parameters from the three rivers within the catchment area. The $\mathrm{pH}$ of the river water sampled range between $6.68-7.79$. This agrees with the findings of Kalff and Knoechel (1998), which reported that water from the limestone belt are perpetually rich in $\mathrm{Ca}$, carbonate and bicarbonate ion and have $\mathrm{pH}$ range from 6.8 9.6. The concentration of $\mathrm{Ca}$ and $\mathrm{Mg}$ are directly related to the geological formation of the area which is in the Basement Complex.

The TSS comprises inorganic salts (primarily $\mathrm{Ca}, \mathrm{Mg}, \mathrm{K}, \mathrm{Na}$, Bicarbonate, Chlorides and Sulphates) and some amount of organic matter that are dissolved in water. TSS and EC are indicators that give the amount and conducting potential of the ionic species in the water sample. These two parameters were generally low and normal for freshwater stream flowing through terrains with no recorded history of severe and $190.80 \mathrm{mg} / \mathrm{l}$ respectively. In Elebute River, nitrate and phosphate levels were $7.05 \mathrm{mg} / \mathrm{l}$ and $14.21 \mathrm{mg} / \mathrm{l}$ respectively and in Itori River nitrate and phosphate concentration were $18.80 \mathrm{mg} / \mathrm{l}$ and $38.20 \mathrm{mg} / \mathrm{l}$ respectively. The higher values of nitrate and phosphate recorded in Alaguntan may be traceable to enhanced nutrient status of the River which was probably due to impact from direct effluent received from cement plant. Omatsola and Adegoke (1981) have equally observed that, water quality impairment are direct result of land use characteristic within the catchment of a receiving stream or river on the one hand and the geological formation of the area on the other.

The heavy metals concentrations in water sample from the three rivers are shown in Table 7. Alaguntan River recorded the highest concentration while Elebute river recorded the least concentration for all the heavy metals except Fe. The higher concentration of heavy metals in Alaguntan River may be attributed to the direct effluent received from the cement factory and its closeness to the pollution source (Fig. 1). On the other hand, Itori River may be linked 
Table 6: Physico-chemical parameters of rivers within the study locations in relation to quality standard for irrigation

\begin{tabular}{lcclll}
\hline Parameter & Units & $\begin{array}{c}\text { Quality Standard } \\
\text { for irrigation }\end{array}$ & & Locations & \\
& & & Alaguntan & Elebute & Itori \\
\hline $\mathrm{pH}$ & & $6.5-8.4$ & 7.79 & 6.68 & 6.87 \\
$\mathrm{EC}$ & $\mathrm{dS} / \mathrm{m}$ & 0.7 & 0.74 & 0.42 & 0.53 \\
$\mathrm{TDS}$ & $\mathrm{mg} / \mathrm{l}$ & 450 & 473.6 & 268.8 & 339.2 \\
$\mathrm{OM}$ & $\mathrm{mg} / \mathrm{l}$ & & 2.2 & 2.59 & 3.52 \\
$\mathrm{SAR}$ & $\mathrm{mg} / \mathrm{l}$ & 3 & 0.7 & 0.58 & 0.66 \\
$\mathrm{NO}_{3}{ }^{-\mathrm{N}}$ & $\mathrm{mg} / 1$ & $5.0-30.0$ & 83.93 & 7.05 & 18.81 \\
$\mathrm{PO}_{4}{ }^{-}$ & $\mathrm{mg} / 1$ & & 190.8 & 14.21 & 38.2 \\
$\mathrm{Ca}$ & $\mathrm{mg} / 1$ & & 10.87 & 7.82 & 12.49 \\
$\mathrm{Na}$ & $\mathrm{mg} / 1$ & 70 & 3.86 & 1.65 & 1.84 \\
$\mathrm{Mg}$ & $\mathrm{mg} / 1$ & & 50.68 & 8.59 & 3.17 \\
$\mathrm{~K}$ & $\mathrm{mg} / 1$ & & 3.5 & 1.29 & 2.46 \\
$\mathrm{Mn}$ & $\mathrm{mg} / 1$ & 0.2 & 28.48 & 7.66 & 16.37 \\
$\mathrm{Fe}$ & $\mathrm{mg} / 1$ & 5 & 3.79 & 2.38 & 1.61 \\
$\mathrm{Zn}$ & $\mathrm{mg} / 1$ & 2 & 0.98 & 0.21 & 0.42 \\
$\mathrm{Cu}$ & $\mathrm{mg} / 1$ & 0.2 & 1.02 & 0.23 & 0.58 \\
$\mathrm{~Pb}$ & $\mathrm{mg} / 1$ & 5 & 0.16 & 0.04 & 0.14 \\
$\mathrm{Ni}$ & $\mathrm{mg} / 1$ & 0.2 & 2.48 & 0.65 & 1.38 \\
$\mathrm{Cr}$ & $\mathrm{mg} / 1$ & 0.1 & 1.96 & 0.51 & 1.06 \\
$\mathrm{Co}$ & $\mathrm{mg} / 1$ & 0.05 & 0.38 & 0.1 & 0.2 \\
$\mathrm{Cd}$ & $\mathrm{mg} / 1$ & 0.01 & 0.11 & 0.03 & 0.04 \\
\hline
\end{tabular}

*Source: Ayers and Westcott, 1994

with human activities and flow of sewage. The presence of automobile mechanic workshops in the area might be a source of metal inputs through runoff into the river. The distribution of heavy metals in all the rivers followed the order $\mathrm{Mn}>\mathrm{Fe}>\mathrm{Ni}>\mathrm{Cr}>\mathrm{Cu}>\mathrm{Zn}>\mathrm{Co}>\mathrm{Pb}>\mathrm{Cd}$. Comparatively, the heavy metal concentrations were however significantly higher $(\mathrm{p}<0.05)$ in samples from Alaguntan River than in corresponding sample from Elebute and Itori Rivers (Fig. 5). Generally, in all the rivers the observed concentration is higher than the recommended limits for irrigation water except the concentration of $\mathrm{Pb}$ and $\mathrm{Zn}$. However, a comparison of the recorded heavy metals concen- tration world average values carried in solution by major unpolluted rivers as reported by Meybeck et al. (1996), Mn, Pb, Zn Cr and Cd were found to be higher while $\mathrm{Cu}$ and $\mathrm{Fe}$ were found to be less than the world average.

\section{CONCLUSION}

Basically, the concentration of heavy metals in all the rivers studied are on the elevated side (in the order of $\mathrm{mg} / \mathrm{l}$ ) and 1000times worse in heavy metals than expected. Therefore, the rural communities who depended on these rivers for drinking and irrigation are exposed to high risk of heavy metal bio-accumulation. Thus it is important to consider the constant 
Table 7: Heavy metals concentration in water samples

\begin{tabular}{llll}
\hline $\begin{array}{l}\text { Element } \\
\text { mg/l }\end{array}$ & Alaguntan & Elebute & Itori \\
\hline $\mathrm{Mn}$ & 28.48 & 7.66 & 16.37 \\
$\mathrm{Fe}$ & 3.79 & 2.38 & 1.61 \\
$\mathrm{Zn}$ & 0.98 & 0.21 & 0.42 \\
$\mathrm{Cu}$ & 1.02 & 0.23 & 0.58 \\
$\mathrm{~Pb}$ & 0.16 & 0.04 & 0.14 \\
$\mathrm{Ni}$ & 2.48 & 0.65 & 1.38 \\
$\mathrm{Cr}$ & 1.96 & 0.51 & 1.06 \\
$\mathrm{Co}$ & 0.38 & 0.1 & 0.2 \\
$\mathrm{Cd}$ & 0.11 & 0.03 & 0.04 \\
\hline
\end{tabular}

monitoring of various industrial activities on the environmental resources beyond the initial Environmental Impact Assessment (EIA) which often are prerequisites to granting of license of operation to industries.

Some urgent action must be taken to reduce the pollutant production especially the particulate dusts in the cement production since particulate deposition has been seen to be primary to the pollution of soil and the rivers in the study area.

\section{REFERENCES}

Andrey, J. (1987). Bees and their Products as Indicators of Environmental Pollution. Med. Weter 43 (6): 352-356

APHA (1992). Standard Methods for the Examination of Water and Wastewater. 17th Edition, American Public Health Association, Washington DC.

Ayers, R. S. and Westcott, W. S. (1994). Water Quality for Agriculture. FAO Irrigation and Drainage Paper 29. FAO Rome Italy

Bayham, Y. K, Yapici, S., Kocaman, B., Nuhoglu, A. and Cakici, A. (2002). The Effect of Cement Dust on some Soil Characteristics Fresenius Environmental Bulletin 11: 1030-1033
Cembureau (1999). European Cement Association. Best Available Techniques for the Cement Industry. Brussels, Belgium

Chapman, D. and Kimstach, V. (1996). Selection of Water Quality Variables. In Water Quality Assessments - A Guide to Use of Biota, Sediments and Water in Environmental Monitoring. Ed. Deborah Chapman. 2nd Edition. UNESCO/WHO/UNEP. Pp 74 $-89$

Cesar, V. and Lepedus, H. (2001). Peroxidase Activity, Soluble Proteins and Chlorophyll Content in Spruce (Picea abies 1. Karst) Needles Affected by Cement dusts. ACTA Bot. Croatia 60: 227-235

Department of Water Affairs and Forestry (DWAF), (1999). Quality of Domestic Water Supplies. Sampling Guide 2. Department of Health and Water Research Commission Pretoria

El-Fadel, M. Alameddine, I., and El-Mashjary, M. (2005). Environmental Assessment of the Amran Cement Plant. Partners for Health Reform plus, (USAID). Project No. 936-5974. 13 http://www.phrplus.org. Accessed February 10, 2007.

Enviromental Technology Program for Industry (ETPI). (1999). Responding to the Environmental challenge: A survey of Pakistans Manufacturing and Industrial Sector: Cement Industry, Karach, Pakistan. http// wwwetpi.org.pk Accessed February 15, 2007

Fabbri, J., Queen, J. and Rigdon, K. (2004). Southdown Portland Cement Plant, Lyons Colorado: Pollution Effects on soil $\mathrm{pH}$, Water Quality and Vegetation Patterns http// wwwenci-stop/web/pags/Southdown\% 20Portland\%20Cement.htm. Accessed January 13,2007

Gaiero, D. M., Roman, R. G., Depetris, P. J. 
55

\section{Ogedengbe and Oke}

and Kempe, S. (1997). Spatial and Temporal Variability of Total No-Residual Heavy Metals Content in Stream Sediment from the Suquia River System, Cordoba, Argentina. Water, Air and Soil Pollution 93: 303 $-319$

International Institute of Tropical Agriculture (IITA) (2000). Weather Data Report, Ibadan Nigeria

Jalkanen, L, Makinene, A., Hasanen. E. and Juhanoja, J. (2000). The Effects of Large Anthropogenic Particulate Emissions on Atmospheric Aerosols Deposition, and Bioindicatiors in the Eastern Gulf of Finland Region. The Science of the Total Environment 262: 123-136

Kalff, J., and Knoechel, R. (1998). Phytoplankton and their Dynamics in Oligotrophic and Eutrophic Lakes. Ann. Rev. Ecol. Synst 9: $475-495$

Legator, M. S., Singleton, C. R., Morris, D.L. and Philips, D. L. (1998). The Health Effects of Living Near Cement Kilns; A Sympton survey in Midlothian, Texas. Toxicology and Industrial Health 14: 829842

Lepedus, H., Cesar, V. and Suver, M., (2003). The Annual Changes of Chloroplast Pigments Contents in Current and PreviousYear Needles of Norway Spruce (Picea abies L. Karst) Exposed to Cement Dust Pollution. ACTA Bot Croat 62: 27-35

Meybeck, M., Friedrich, G., Thomas, R. and Chapman, D. (1996). Rivers. In Water Quality Assessments - A Guide to Use of Biota, Sediments and Water in Environmental Monitoring 2nd Edition (ed) Deborah Chapman UNESCO/WHO/UNEP

Ocak, I., Sulun, Y. and Hasenekoglu, I. (2004). The Effects of Cement Dust Emitted from Gazia-ntep Cement Pland on Microfungus
Flora of Surroundings Soil. Trakya University

Omatsola, M. E., and Adegoke, O. S. (1981). Tectonic and Cretaceous Stratigraphy of the Dahomey Basin. Journal of Mining Geology 18: $130-137$

Perfettini, J. V., Lango, M. N., Reverbega, T E., Petil, J. K., Gaylend, C.C. and. Mortan, L.H.G (eds). (1989). Evaluation of the Cement Degradation Induced by the Metabolic Products of Two Fungal Strains Biodeterioration Society Occassional Publication No 5.

Ponsby, A. L., Couper, D., Dwyer, T., Carmichael, A., Kemp, A. and Cochrane, J. (2000). The Relation Between Infant Indoor and Environment and Subsequent Asthma. Epidemiology 11: pp128-135

Sivakumar, S., and Britto, A. J. (1995). Effect of Cement Pollution on Soil Fertility. Journal of Ecotoxicology and Environmental Monitoring 5 (2): 147- 149

United States Census Bureau (2000). Economic Census. http//www.census.gov/epcd/www/ econ97.html. Accessed February 12, 2007

Van Oss, H. G. and Padovoni, A. C. (2003). Cement Manufacturing and the Envrionment, Part II. Environmental Challenges and Opportunities, Massachusetts Institute of Technology and Yale University. 7 (1): 93-126

Wang, H. D., Ryan, L. and Xu, X. (1997). Association between Air Pollution and Low Birth Weight: A Community Based Study. Environmental Health Perspectives 105: 514-520

West African Portland Cement (2000). Environmental Audit Report of the West Arican Portland Cement PLC. Ewekoro Sagamu Quarries. Submitted to the Federal Ministry 
Pollution impact of cement... 56

of Environment, Abuja by the West African Portland Cement Plc, Elephant House, Ikeja Lagos, Nigeria. 1-155

World Health Organization (1999). Public Health and Chemical Incidents: Guidance for National and Regional Policy Makers Cardiff U.K: University of Wales Institute, WHO Collaborating Centre for Chemical incidents.
World Bank (1998). Pollution prevention and Abatement Hand Book - Part III: Cement Manufacturing Washington, D.C., World Bank, United States.

Ziadat, A. H., Batarseh, M., El-Hassan, T., Berdanie. B. W. and Jiries, A. (2006). Chemical and Mineralogical Characteristics of Dry Deposition in the Surrounding of a Cement Factory in Jordan. Journal of Environmental Foresics 7: 169-174 